\title{
Akateemisesta opiskelusta ja opetuksesta
}

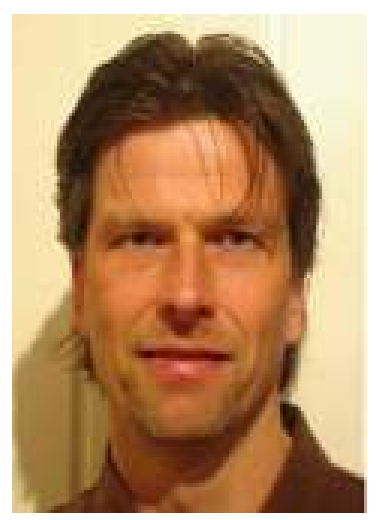

Petri Salo
A leen) kasapäin yliopisto- ja korkeakoulupedagogisia teemoja ja haasteita käsitteleviä käsikirjoituksia ja tekstejä. Paine teemanumeron julkaisemiseen on syntynyt kuin itsestään, oman tieteenalamme ulkopuolella. Sillä eihän yliopisto-opetuksen tutkiva kehittäminen ole aikuiskasvatusta? Hylättyjen käsikirjoitusten perusteella yliopistopedagoginen tutkimus on teoreettis-empiirisesti pienimuotoista ja vahvasti tiettyyn paikallis-organisatoriseen kontekstiin kiinnittynyttä. Tutkimusta ohjaa usein kehittämisen ja arvioinnin tarve tai pakko. Kyseisin kriteerein ei eroa aikuiskasvatustieteeseen kuitenkaan synny - päinvastoin.

Jos sliopistopedagogiikassa tutkitaan vain yliopistoissa annettavaa opetusta, opiskeljoiden opiskelua ja oppimista, on se nähdäkseni paljolti soveltava kasvatustieteiden tieteenala. Pidemmälle ja laajemmalle kantava kontekstualisointi edellyttäisi aina lähtökohtaisesti vastauksia kysymyksiin; mikä yliopisto on, mikä on sen tehtävä ja miksi yliopistossa opiskellaan. Aikuiskasvatuksellinen ote edellyttää nähdäkseni esimerkiksi opiskelun kulttuuristen, sosiaalisten ja yhteiskunnallisten lähtökohtien ja edellytysten huomioimista - vastausta kysymykseen, mikä ja kuka yliopisto-opiskelija on sekä miksi hän yliopistossa opiskelee. Ruotsissa korkeakoulupedagogiikka on jo pitkään ymmärretty aikuiskasvatustieteen osaalueeksi. Osasyynä tähän lienee se, että naapurimaassamme ns. avoimen yliopiston väylä toiminut tehokkaasti jo vuosikymmenet. Aikuisten osuus yliopisto-opiskelijoista on jo pitkään ollut huomattava. "Kansankotikorkeakoululla" on myös ollut ja on yhä edelleen myös pakolaisia ja maahanmuuttajia integroiva (eli kansainvälisyyttä edistävä?) tehtävä. Tilanne on kuitenkin muuttummassa.

Y liopisto-opettajan tehtävä (jo) kuudennen hullun yliopistovuoden alkaessa on puristaa massa yhä tehokkaammin ja tuloksellisemmin sylinterin läpi. Pahimmillaan yliopistopedagogiset opinnot ja valmiudet toimivat ainoastaan synteettisenä, kitkaa vähentävänä voitelyöljynä. Yliopistojen hallinnollisissa norsunluutorneissa puolestaan näytetään toimittavan määrätietoisen tehokkaasti ajan henkeä vastaan. Kun aikamme ja yhteiskuntamme vaikuttaa muuten painekyllästetyn sekä-että-toiminnalla, vaikuttaa yliopisto-opetuksen kehittäminen edellyttävän tutkimuksen ja opetuksen yhä tiukempaa erottelua toisistaan. En ole yliopistopedagogisista työkalupakista ainakaan toistaiseksi löytänyt käsitteitä tutkimusopetus tai opetustutkimus. Toimintatutkimus-työkalukin näyttää pahasti ruostuneelta. Opiskelijoiden työssäkäynti, eli toimiminen sekä opiskelijan että työntekija-veronmaksajan roolissa, määritellään ongelmaksi, vaikka työpaikalla saattaa jotakin oppiakin. Tämän oppimisen yhteiskunnallisten, sosiaalisten, poliittisten, taloudellisten tai organisatoristen lähtökohtien ja edellytysten itsereflektiiviseen 
analyysiin opiskelijan olisi ollut hyvä saada esimerkiksi perusopintojensa yhteydessä tieteellisen ajattelun välineitä. Toisen asteen ammatillisessa koulutuksessa on jo viime vuosisadan lopulta alkaen pohdittu ja kehitelty näyttötutkintoja ja työssä oppimista.

$\mathrm{M}$

utta tottahan akateemisessa norsunluutornissakin olisi vihdoin havahduttava ja herättävä siihen, että maailma on muuttunut eikä mikään ole kuin ennen! Johan Wilhelm Snellmanin vuonna 1840 julkaisema tutkimus otsikolla "Akateemisesta opiskelusta" on, kuten Juha Himanka artikkelissaan toteaa, yliopistoopetuksen käytännön ja järjestämisen näkökulmasta (maailman muuttumisesta huolimatta) hämmästyttävän ajankohtainen. Siitä olisikin mielestäni yliopistopedagogiseksi oppaaksi sekä massayliopistoon että innovaatiokorkeakouluun. Ongelmaksi muodostuu kuitenkin se, että Snellman määrittelee yliopiston sivistyslaitokseksi, jonka tehtävänä on toimia tieteen vaalijana ja edistää senluonteista tietämistä, joka eroaa koulun muistitietämisestä. Snellman ei myöskään vaikuta innostuvan virkamiestutkintojen tehtaana toimivasta yliopistosta.

Snellmanin yliopistopedagogisena johtotähtenä on, kuten Juha Himankakin on asian tulkinnut, kannustaa ja johdattaa opiskelijat itsenäisen ja itseohjautuvan toiminnan kautta itsetietoiseen ja itsereflektiiviseen, eli "aikuismaiseen" opiskeluun ja oppimiseen. Jos pystyisimme kannustamaan opiskelijoita olemaan "itsensä” yhdessä muiden kanssa ja edistämään heidän ymmärystään koskien sitä, että opiskelu ja oppiminen lähtee heistä itsestään, olisi paljon voitettu. Voisimme toimia aikuiskasvattajina.

\section{$S$}

nellmanille "yliopisto on laitos, jonka tarkoituksena on kasvattaa ajatteleva ja tahtova subjekti tietämiseen ja eettisyyteen, sovitukseen itsetajunnan ja tradition välillä.” (s.16) Yliopistopedagogisena työvälineenä toimii "tutkimusopetus" (käsite omani), jonka mukaisesti "yliopistonopettajan pitää kaikkialla luennoissaan osoittaa, että hänen tietämisensä on omaa tutkimusta, hänen ei pidä esittää vain tuloksia, vaan siinä määrin kuin mahdollista opastaa oppilasta sille tielle, jonka hän on itse vaeltanut." (s. 24). Yliopistotutkinnon suorittaneen henkilön (Snellmanin tekstissä miehen) tulee kyetä esittämään perusteltu näkemys tieteensä nykyisestä tilasta, osoittamaan yksityiskohtaisesti, mitä kiitettävää tai kritisoitavaa tietyn tutkijan käsityksissä kyseisellä tieteenalalla on sekä selvittämään oman tieteenalansa tutkimukseen perustuen jokin tärkeä yhteiskunnallinen kysymys. (s. 9). Selkeät ja mainiot sisällölliset kriteerit esimerkiksi aikuiskasvatustieteen pro gradu -töitä ja väitöskirjoja ohjaaville yliopisto-opettajille ja professoreille. Yhteiskuntavastuukin toteutuu kolmannen kriteerin kohdalla.

\section{Petri Salo}

psalo@abo.fi

Lähde: Snellman, J.V. 1999/1840. Akateemisesta opiskelusta. Om det akademiska studium. Helsinki: Snellman-korkeakoulun julkaisuja No:1. 